\begin{tabular}{|l|l|l|}
\hline \multicolumn{2}{|c|}{ PublisherInfo } \\
\hline \hline PublisherName & $:$ & BioMed Central \\
\hline \hline PublisherLocation & $:$ & London \\
\hline \hline PublisherImprintName & $:$ & BioMed Central \\
\hline \hline
\end{tabular}

\title{
Genetic alterations in normal breast tissue
}

\begin{tabular}{||l|l|l||}
\hline \multicolumn{2}{|c||}{ ArticleInfo } \\
\hline \hline ArticleID & $:$ & 3666 \\
\hline \hline ArticleDOI & $:$ & $10.1186 /$ bcr-1999-66644 \\
\hline \hline ArticleCitationID & $:$ & 66644 \\
\hline \hline ArticleSequenceNumber & $:$ & 32 \\
\hline \hline ArticleCategory & $:$ & Paper Report \\
\hline \hline ArticleFirstPage & $:$ & 1 \\
\hline \hline ArticleLastPage & $:$ & 4 \\
\hline \hline & $:$ & RegistrationDate : 1999-12-23 \\
ArticleHistory & $:$ & OnlineDate \\
\hline \hline ArticleCopyright & $:$ & Current Science Ltd1999-12-23 \\
\hline \hline ArticleGrants & $:$ & \\
\hline \hline ArticleContext & $:$ & 1305822 \\
\hline \hline
\end{tabular}




\section{Keywords}

breast, epithelium, genetic alteration, loss of heterozygosity, luminal, myoepithelium, normal tissue,

\section{Introduction}

There is a growing body of genetic data that supports the existence of precancerous breast lesions. Loss of heterozygosity ( $\mathrm{LOH}$ ) has been described in a number of in situ proliferations and a proposed multistep model suggests that breast carcinoma arises through intermediate hyperplastic and neoplastic stages. However, LOH has also been identified in morphologically normal breast lobules adjacent to breast carcinomas. This suggests that the normal lobule may be clonal.

\section{Aims}

To study whether LOH is present in normal lobules and if so whether the existence of a common stem cell for both epithelial and myoepithelial cells can be supported.

\section{Comments}

This study confirms the finding that $\mathrm{LOH}$ can be detected in normal lobules. It thus supports the notion that normal lobules are clonal. The presence of LOH in both epithelial and myoepithelial cells adds further weight to the existence of a common stem cell. It would be interesting to take this study further and to identify the extent of clonality, if present, within normal breast. Is it confined to a single terminal duct lobular unit or are a group of lobules all clonal? The advent of laser microdissection may make it possible to answer these questions. This study also raises doubts on the significance of LOH in precancerous breast lesions if it can be detected in normal tissue from noncancerous breasts. Further work is required to identify whether or not normal lobules or precancerous breast lesions that contain $\mathrm{LOH}$ are at a higher risk of developing carcinoma.

\section{Methods}


The samples comprised normal tissues from 10 cases with carcinoma and from 3 reduction mammoplasties. Two cases had a family history of breast disease, one with a known germline mutation in the BRCA1 gene. A piece of fresh tumour tissue with some adjacent normal tissue was used for the in vitrocloning. For cloning, the tissues were disagregated with collagenase and cultured on mouse 3T6 fibroblasts. After 10-14 days the clones consisted of 1000-5000 cells and were identified as either of luminal or myoepithelial origin using phase-contrast morphology. The clones were then individually harvested by conventional ring-cloning techniques.For the $\mathrm{LOH}$ analysis tumour and normal ductlobular units were dissected using the fine point of a glass pippette. LOH was performed by amplification of polymorphic microsatellite markers using fluorescence tagged primers and the polymerase chain reaction. The dinucleotide repeats used were D3s1597 (3p24.2), D3s1578 (3p21.1), D11s902 (11p15), D13s267 (13q13), D16s413 (16q24.3), D17s796 (17p13.2) and D17s250 (17q12). A value of 0.5 or less was used as indicative of LOH.Comparative genomic hybridisation $(\mathrm{CGH})$ analysis was carried out on one case that showed $\mathrm{LOH}$ at the same allele within an invasive tumour and one luminal and one myoepithelial clone. Sequence analysis in the patient with a known BRCA1 mutation was also performed.

\section{Results}

Clones were analysed from malignant breasts $(\mathrm{n}=392)$ and reduction mammoplasties $(\mathrm{n}=93)$. Microdissected tumour and normal tissue from paraffin-embedded blocks was also examined. In two cases LOH was not identified. In a further three cases LOH was present, at 1-6 loci, in tumour but not normal tissue. However, five cases showed LOH in normal tissue. Furthermore, of the three reduction mammoplasties, one case showed LOH in a single myoepithelial clone. The case with the BRCA1 mutation showed LOH at 3 loci within the tumour. LOH was also identified in 4 of 33 clones, all derived from tissue distant from the tumour. Sequencing exon 20 of the BRCA1 gene showed that one clone had deletion of the mutant allele whereas the tumour and another clone had lost the wild type allele. CGH analysis showed that a tumour had widespread DNA copy number changes whilst the normal clones showed only minor abnormalities.

\section{Discussion}

This study confirms that the LOH identified in invasive carcinoma can be seen in normal tissue. Furthermore LOH is detected independently in both the luminal and the myoepithelial cell types. This suggests the existence of a common stem cell that gives rise to the two breast cell types by differentiation. The finding of $\mathrm{LOH}$ in normal breast epithelial and myoepithelial cells adds further support to the multistep hypothesis for breast carcinogenesis. 


\section{References}

1. Lakhani SR, Chaggar R, Chaggar R : Genetic alterations in normal luminal and myoepithelial cells of the breast. J Pathol. 1999, 189 : 496-503. 